\title{
Possible involvement of interferon alfa in the pathogenesis of fever in systemic lupus erythematosus
}

\author{
YOSHIHARU KANAYAMA, TOMOIKU KIM, HIROMI INARIBA, \\ NOBUO NEGORO, MIKIO OKAMURA, TADANAO TAKEDA, AND \\ TAKATOSHI INOUE
}

From the first Department of Internal Medicine, Osaka City University Medical School, 1-5-7 Asahimachi, Abeno-ku, Osaka 545, Japan

SUMMARY Serum concentrations of interferon alfa, interleukin 1, and tumour necrosis factor $\alpha$ were measured in 25 untreated patients with systemic lupus erythematosus (SLE). A close correlation was found between serum concentrations of interferon alfa and the degree of fever, while no significant correlations were found between fever and interleukin 1 or tumour necrosis factor $\alpha$. These results suggest the possible involvement of interferon alfa in the pathogenesis of fever in SLE.

Fever is one of the cardinal symptoms of systemic lupus erythematosus (SLE). The pathogenesis of fever in patients with SLE remains unclear, however. Recent investigations showed that interleukin 1 , interferon alfa, tumour necrosis factor $\alpha$, and interleukin 6 are cytokines which can induced fever in vivo. ${ }^{1-5}$ We previously found an increase in the serum concentrations of interferon alfa in patients with SLE. ${ }^{6}$ In this study we measured serum concentrations of interferon alfa, interleukin 1 , and tumour necrosis factor $\alpha$ in 25 untreated patients with SLE by radioimmunoassay and enzyme linked immunosorbent assay (ELISA) to examine which cytokine(s) is involved in the pathogenesis of fever in patients with SLE.

\section{Patients and methods}

Serum samples were obtained from 25 patients with SLE who fulfilled the 1982 revised criteria for the classification of SLE. ${ }^{7}$ None of the patients had received corticosteroids or anti-inflammatory agents at the time of serum collection. Control serum samples were obtained from 17 healthy laboratory

Accepted for publication 31 May 1989.

Correspondence to Dr Yoshiharu Kanayama, First Department of Internal Medicine, Osaka City University Medical School, 1-5-7 Asahimachi, Abeno-ku, Osaka 545, Japan. personnel, whose body temperatures were normal or below $36.9^{\circ} \mathrm{C}$. Serum samples were stored at $-80^{\circ} \mathrm{C}$ until assayed.

Serum concentrations of interferon alfa were measured by radioimmunoassay. ${ }^{6}$ The detection limit of the assay was $1 \mathrm{U} / \mathrm{ml}$. Serum concentrations of interleukin 1 were assayed by an ELISA kit (Cistron Biotechnology, NJ, USA) using a monoclonal antibody specific for interleukin $1 \beta$. The detection limit of the assay was $20 \mathrm{pg} / \mathrm{ml}$. Tumour necrosis factor $\alpha$ concentrations were determined by a radioimmunoassay kit (Medgenix, Brussels, Belgium) using polyclonal antibody against tumour necrosis factor $\alpha$. The detection limit of the assay was around $50 \mathrm{pg} / \mathrm{ml}$.

The peak body temperature of the patient on the day of serum collection was designated as the degree of fever of the patient (body temperature was measured four times a day).

Statistics used were the Mann-Whitney U test and the non-parametric rank order correlation method where appropriate.

\section{Results}

Table 1 shows the degree of fever and serum concentrations of interferon alfa, interleukin $1 \beta$, and tumour necrosis factor $\alpha$. Serum concentrations of interferon alfa in patients with SLE were higher 
than those of controls (15.4 (SD 24.0) U/ml $v$ below the detection limit, $\mathrm{p}<0.001)$ and closely correlated with the degree of fever $(r s=0.828, p<0.001)$ (Fig. $1)$. Serum concentrations of interleukin $1 \beta$ were modestly increased in patients with SLE compared with controls (86.4 (SD 120.6) v 21.6 (47.0) pg/ml, $\mathrm{p}<0.05)$, and serum concentrations of tumour necrosis factor $\alpha$ were also significantly higher in patients with SLE than those in controls $(256 \cdot 1$ (106.5) v 166.1 (36.6) $\mathrm{pg} / \mathrm{ml}, \dot{\mathrm{p}}<0.001)$. Neither interleukin $1 \beta$ nor tumour necrosis factor $\alpha$ correlated with the degree of fever in patients with SLE (rs $=0.097,0.164$ respectively). Although two patients $($ Nos 7,2$)$ with the highest and the second highest interleukin $1 \beta$ concentrations were both febrile their serum concentrations of interferon alfa were also high. In contrast, patient No 17 with the third highest concentration of interleukin $1 \beta$ was not febrile and her serum concentration of interferon alfa was low. Patient No 18 with the highest serum concentration of tumour necrosis factor $\alpha$ was not febrile and her serum concentration of interferon alfa was low (Table 1).

Table 1 Degree of fever and serum concentrations of interferon alfa, interleukin $1 \beta$, and tumour necrosis factor $\alpha$ in patients with systemic lupus erythematosus

\begin{tabular}{|c|c|c|c|c|}
\hline $\begin{array}{l}\text { Patient } \\
\text { No }\end{array}$ & $\begin{array}{l}\text { Degree of } \\
\text { fever }\left({ }^{\circ} \mathrm{C}\right)\end{array}$ & $\begin{array}{l}\alpha-I N F^{*} \\
(U / m l)\end{array}$ & $\begin{array}{l}I L-I \beta^{*} \\
(p g / m l)\end{array}$ & $\begin{array}{l}T N F-\alpha^{*} \\
(p g / m l)\end{array}$ \\
\hline 1 & $40 \cdot 0$ & $110 \cdot 0$ & 102 & 276 \\
\hline 2 & 39.7 & $58 \cdot 0$ & 390 & 199 \\
\hline 3 & $39 \cdot 5$ & $40 \cdot 0$ & ND & 286 \\
\hline 4 & $39 \cdot 0$ & $23 \cdot 0$ & ND & 282 \\
\hline 5 & $38 \cdot 5$ & $15 \cdot 0$ & 86 & 252 \\
\hline 6 & $38 \cdot 2$ & $21 \cdot 0$ & ND & 395 \\
\hline 7 & $38 \cdot 0$ & $23 \cdot 0$ & 480 & 288 \\
\hline 8 & $37 \cdot 9$ & $12 \cdot 0$ & ND & 206 \\
\hline 9 & $37 \cdot 8$ & $18 \cdot 0$ & 40 & 109 \\
\hline 10 & $37 \cdot 8$ & $2 \cdot 0$ & 58 & 216 \\
\hline 11 & $37 \cdot 8$ & $2 \cdot 0$ & ND & 197 \\
\hline 12 & $37 \cdot 6$ & 5.9 & 38 & 294 \\
\hline 13 & $37 \cdot 4$ & $8 \cdot 1$ & 38 & 168 \\
\hline 14 & 37.4 & $2 \cdot 2$ & ND & 259 \\
\hline 15 & $37 \cdot 2$ & $9 \cdot 8$ & 50 & 277 \\
\hline 16 & $37 \cdot 2$ & $8 \cdot 5$ & 120 & 240 \\
\hline 17 & $37 \cdot 2$ & $2 \cdot 2$ & 218 & 178 \\
\hline 18 & $37 \cdot 0$ & $3 \cdot 5$ & ND & 679 \\
\hline 19 & $37 \cdot 0$ & $2 \cdot 8$ & 65 & 264 \\
\hline 20 & $36 \cdot 8$ & $5 \cdot 2$ & ND & 219 \\
\hline 21 & $36 \cdot 8$ & 6.9 & 155 & 309 \\
\hline 22 & $36 \cdot 7$ & $1 \cdot 2$ & 104 & 215 \\
\hline 23 & $36 \cdot 7$ & $1 \cdot 5$ & 125 & 240 \\
\hline 24 & $36 \cdot 7$ & $\mathrm{ND}^{*}$ & ND & 133 \\
\hline 25 & 36.7 & $1 \cdot 2$ & 90 & 222 \\
\hline
\end{tabular}

${ }^{*} \alpha$-INF=interferon alfa; IL-1 $\beta=$ interleukin $1 \beta ;$ TNF- $\alpha=$ tumour necrosis factor $\alpha ; N D=$ not detected, below the sensitivity limit of the assays.

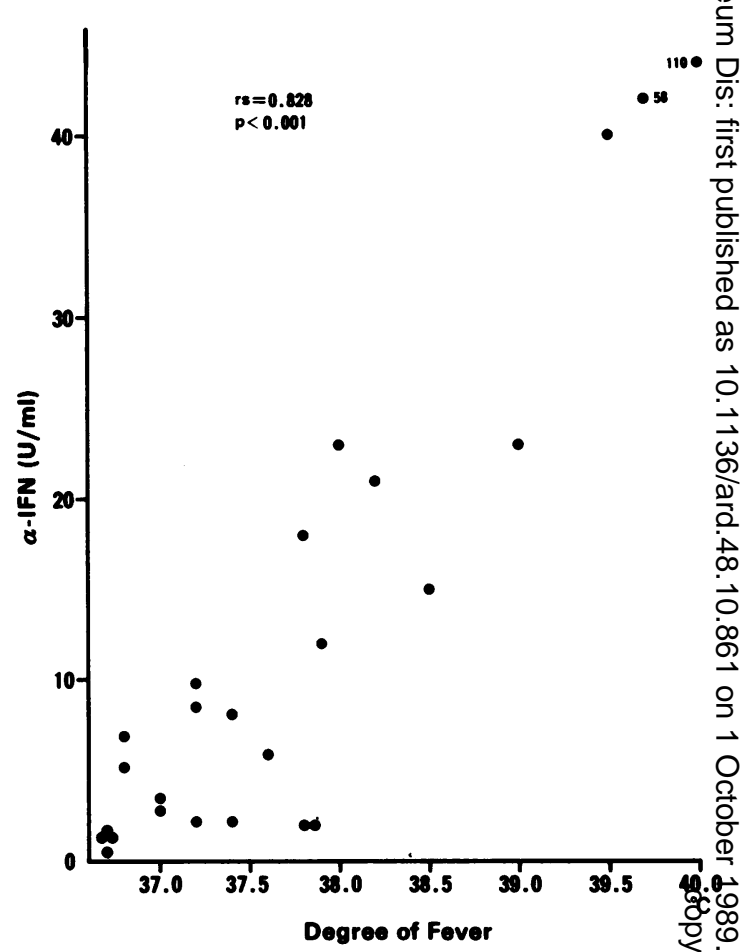

Fig. 1 Correlation of the degree of fever with serain concentrations of interferon alfa $(\alpha-I F N)$.

\section{Discussion}

We found a close correlation between the degree of fever and the serum concentrations of interferon? alfa in patients with SLE, whereas no correlationso were found between the serum concentrations of interleukin $1 \beta$ or tumour necrosis factor $\alpha$ with fever. Patients with high serum concentrations of interleukin $1 \beta$ or tumour necrosis factor $\alpha$ were not febrile. Although we did not examine the temporal relation between fever and serum concentrations of 5 these cytokines, these results suggest a possible involvement of interferon alfa in the pathogenesis of fever in SLE.

In contrast with the case of bacterial infections febrile patients with SLE usually show leucopenia and there is no increase or only a small increase of acute phase proteins such as $\mathrm{C}$ reactive protein. ${ }^{8}$ If has been shown that interleukin 1 , tumour necrosis? factor $\alpha$, and interleukin 6 increase the acute phased proteins, ${ }^{15910}$ thus suggesting that a different cytokine may be a mediator of fever in SLE, which could explain the different febrile conditions in SLE. 


\section{References}

1 Dinarello C A. Interleukin-1 and the pathogenesis of the acutephase response. $N$ Engl $J$ Med 1984; 311: 1413-8.

2 Dinarello C A, Bernheim H A, Duff G W, et al. Mechanisms of fever induced by recombinant human interferon. J Clin Invest 1984; 74: 906-13.

3 Dinarello C A, Cannon J G, Wolff S M, et al. Tumor necrosis factor (cachectin) is an endogenous pyrogen and induces production of interleukin 1. J Exp Med 1986; 163: 1433-50.

4 Michie H R, Manogue K R, Spriggs D R, et al. Detection of circulating tumor necrosis factor after endotoxin administration. $N$ Engl J Med 1988; 318: 1481-6.

5 Nijsten M W N, De Groot E R, Ten Duis H J, Klasen H J, Hack C E, Aarden L A. Serum levels of interleukin 6 and acute phase responses. Lancet 1987; ii: 921.
6 Kim T, Kanayama Y, Negoro N, Okamura M, Takeda T, Inoue $\mathrm{T}$. Serum levels of interferons in patients with systemic lupus erythematosus. Clin Exp Immunol 1987; 70: 562-9.

7 Tan E M, Cohen A S, Fries J F, et al. The 1982 revised criteria for the classification of systemic lupus erythematosus. Arthritis Rheum 1982; 25: 1271-7.

8 Dinarello C A, Wier J W. Lymphokines. N Engl J Med 1987; 317: $940-5$.

9 Becker G J, Waldburger M, Hughes G R V, Pepys M B. Value of $C$ reactive protein measurement in the investigation of fever in systemic lupus erythematosus. Ann Rheum Dis 1980; 39: 50-2.

10 Moshage H J, Roelofs H M J, van Pelt J F, et al. The effect of interleukin-1, interleukin-6 and its interrelationship on the synthesis of serum amyloid and C-reactive protein in primary cultures of adult hepatocytes. Biochem Biophys Res Commun 1988; 155: 112-7. 